\title{
The antioxidant, anticancer and anticoagulant activities of Acanthus ilicifolius L. roots and Lumnitzera racemosa Willd. leaves, from southeast coast of India
}

\author{
Tanvira Paul, Seenivasan Ramasubbu
}

Department of Bio-Medical Sciences, School of Bio Science \& Technology, VIT University, Vellore, 632014, Tamil Nadu, India.

\begin{tabular}{l} 
ARTICLE INFO \\
\hline Article history: \\
Received on: 30/04/2016 \\
Accepted on: $23 / 08 / 2016$ \\
Available online: $30 / 03 / 2017$ \\
\hline Key words: \\
Acanthus ilicifolius, \\
Lumnitzera racemosa, \\
Mangroves, Antioxidant, \\
Anticancer, Anticoagulant.
\end{tabular}

\begin{abstract}
The present study was designed to evaluate and determine the phytochemical composition, antioxidant, anticancer and anticoagulant activities of the aqueous extracts of Acanthus ilicifolius roots and Lumnitzera racemosa leaves from Pichavaram mangrove forest, Tamil Nadu, India based on folklore knowledge. The preliminary phytochemical screening revealed the presence of the following classes of bioactive compounds: phenols, flavonoids, alkaloids, terpenoids, sterols, tannins, carbohydrates, cardiac glycosides, saponins and quinones. The total phenolic content was reported much higher as compared to the total flavonoid content mainly in the leaf extract of L.racemosa. This mostly contributes to the antioxidant power of the extracts, which is affirmed by the $\mathrm{IC}_{50}$ values of the crude extracts in the DPPH assay, which was lower than the ABTS assay. The FRAP assay also exhibited a consistent increase in reducing ability with increase in the concentration which is indicative of the extract's antioxidant potential. The extracts were also reported to exhibit in vitro cytotoxicity and apoptosis inducing ability in Hep G2 cancer cells. And the anticoagulant study conducted provided a first hand report for the plants exhibiting the property. However, further studies must be conducted for secondary metabolite profiling to decipher and clarify the compound(s) responsible for the reported activities of the plant crude extracts.
\end{abstract}

\section{INTRODUCTION}

Mangroves are a category of plants, the use of which for medicinal purposes dates back to the year 1230 (Bandaranayake, 1998). The current study aims at documenting a maiden report on the antioxidant, anti-cancerous and anticoagulant properties of specific parts of the mangrove species: Acanthus ilicifolius L. (Acanthaceae) and Lumnitzera racemosa Willd. (Combretaceae), based on folklore knowledge, from the Pichavaram mangrove forest situated in the state of Tamil Nadu, India. Prominent survey reports from India suggests the use of roots of Acanthus ilicifolius and leaves of Lumnitzera racemosa for treatment of snake bites, rheumatism, skin allergies, blood purifier, asthma, diabetics etc. (Bandaranayake, 1998; Pattanaik et al., 2008) And as such, the specific plant parts were collected

* Corresponding Author

Email: rseenivasan @ vit.ac.in to primarily investigate their phytochemical \& antioxidant properties and their role as anti-cancer agents. They were also tested for blood anti-coagulating property, which in sum would scientifically validate their folklore functionality.

\section{MATERIALS AND METHODS}

\section{Sample collection and authentication}

Fresh samples of mangroves (Acanthus ilicifolius and Lumnitzera racemosa) were collected from Pichavaram mangrove forest located along the southeastern coastline, in the state of Tamil Nadu, India. Guided by the knowledge of folklore use of plants for different medicinal purposes, specifically, the roots of Acanthus ilicifolius and the leaves of Lumnitzera racemosa were collected from this region during the month of April-May 2013. The plant sample specimens were identified and preserved in the herbarium under the collection number AUCASMBTR01 and AUCASMBTR 09. 


\section{Sample preparation and extraction}

The plant samples collected were then thoroughly washed with distilled water for the removal of contaminants, mud and dirt. After shade drying at room temperature for 3-4 days, the plant samples were pulverized for use in the extraction purpose.

For the preparation of extracts (root and leaf), $5 \mathrm{~g}$ of the powdered plant parts (root and leaf) were soaked in $50 \mathrm{ml}$ of water in a beaker and was kept on a magnetic stirrer for $24 \mathrm{~h}$ at room temperature. The extracts were then filtered using Whatman No. 1 filter paper and the filtrates were concentrated using rotary vacuum evaporator. The dried extracts were finally stored at $-20{ }^{\circ} \mathrm{C}$ until further use (Solomon Charles Ugochukwu et al., 2013).

\section{Chemicals, reagents and cell lines}

All the chemicals and reagents used in the phytochemical and antioxidant assays were obtained from the certified suppliers and were of the highest analytical grade. The Hep G2 (human liver hepatocellular carcinoma) cell line was procured from the cell repository of National Center for Cell Science (NCCS), Pune, India. Liquicelin-E and Liquiplastin reagents, for the anticoagulation studies were purchased from Tulip Diagnostics Pvt. Ltd., India.

\section{Phytochemical screening of the extracts}

Using standard protocol (Solomon Charles Ugochukwu et al., 2013), the freshly prepared aqueous extracts were subjected to qualitative phytochemical screening for detecting the presence of the following bioactive chemical constituents: phenols, flavonoids, alkaloids, terpenoids, sterols, tannins, proteins and amino acids, carbohydrates, cardiac glycosides, saponins and quinones.

\section{Determination of total phenolic content (TPC)}

The standard protocol (Ainsworth and Gillespie, 2007; Barku et al., 2013) for estimating the total phenol content of the extracts using Folin-Ciocalteu reagent was adapted with little modifications. Gallic acid $(20-100 \mu \mathrm{g} / \mathrm{ml})$ was used as a standard. To a volume of $1 \mathrm{ml}(100 \mu \mathrm{g} / \mathrm{ml})$ of aqueous plant extract, $5 \mathrm{ml}$ of Folin-Ciocalteu reagent (diluted to 10 folds) and $4 \mathrm{ml}$ of sodium carbonate solution $(7.5 \%)$ were added. The reaction mix was then allowed to stand in dark at room temperature for $30 \mathrm{~min}$ and absorbance of the blue color developed was recorded at a wavelength of $765 \mathrm{~nm}$ using a Shimadzu UV-1800 UV-VIS spectrophotometer (Shimadzu, Kyoto, Japan). The TPC of the extracts were determined using the linear regression equation acquired by plotting gallic acid standard curve. The results were calculated as mean $\pm \mathrm{SD}(\mathrm{n}=3)$ and expressed as $\mu \mathrm{g} / \mathrm{ml}$ of gallic acid equivalent (GAE) of dry extract.

\section{Determination of total flavonoid content (TFC)}

The aluminium chloride colorimetric method (Barku et al., 2013) was used for determining the total flavonoid content of the plant aqueous extracts. Quercetin $(20-100 \mu \mathrm{g} / \mathrm{ml})$ was used as the standard. Each plant extract $(1 \mathrm{mg} / \mathrm{ml}, 0.25 \mathrm{ml})$ was added to
$1.25 \mathrm{ml}$ of distilled water and then $0.075 \mathrm{ml}$ of sodium nitrite solution $(5 \%)$ was added. The reaction mix was incubated at room temperature for $5 \mathrm{~min}$, following which $0.15 \mathrm{ml}$ of $10 \%$ aluminum chloride solution was added and the mix was again allowed to stand for another $6 \mathrm{~min}$ at room temperature before adding $0.5 \mathrm{ml}$ of $1 \mathrm{M}$ sodium hydroxide solution and finally diluting the reaction mix with $0.275 \mathrm{ml}$ of distilled water. The absorbance was recorded at $510 \mathrm{~nm}$ in a Shimadzu UV-1800 UV-VIS spectrophotometer (Shimadzu, Kyoto, Japan). The TFC of the plant extracts were calculated as mean $\pm \mathrm{SD}$ ( $\mathrm{n}=3$ ) using the linear regression equation obtained by plotting quercetin standard curve and expressed as $\mu \mathrm{g} / \mathrm{ml}$ of quercetin equivalent (QE) of dry extract.

\section{In vitro antioxidant assays \\ DPPH radical scavenging activity}

The scavenging activity of the plant aqueous extracts against DPPH (2-diphenyl-2-picrylhydrazyl) radical was determined by the standard method (Banerjee et al., 2008; Zheleva-Dimitrova et al., 2010), with few modifications. An aliquot of $200 \mu \mathrm{l}$ of different concentrations $(20-100 \mu \mathrm{g} / \mathrm{ml})$ of each of the extracts was mixed with $3.9 \mathrm{ml}$ of freshly prepared DPPH solution $(25 \mathrm{mg} / \mathrm{L})$ in methanol. The reaction mixture was mixed and incubated for $30 \mathrm{~min}$ at room temperature in dark and its absorbance was recorded at $517 \mathrm{~nm}$. Ascorbic acid was used as the reference standard. The DPPH scavenging capability was calculated using the following equation:

$$
\begin{aligned}
& \begin{array}{l}
\text { DPPH radical } \\
\text { scavenging }_{\text {activity }(\%)}
\end{array}=\left[\left(\mathrm{Abs}_{(\text {control })}-\mathrm{Abs}_{(\text {sample })}\right) / \mathrm{Abs}_{(\text {control })}\right] \times 100
\end{aligned}
$$

where Abs (control) is the absorbance of the DPPH radical in methanol; Abs (sample) is the absorbance of the DPPH solution in presence of the aqueous extract or standard. The antioxidant value was expressed as $\mathrm{IC}_{50}$, which is defined as the concentration in $\mu \mathrm{g}$ of the dry extract per $\mathrm{ml}$ that inhibits the formation of DPPH radical by $50 \%$. Each value was determined from the slope of the linear regression equation $(y=m x+c)$, obtained by plotting the ascorbic acid standard curve. All results were calculated as mean \pm $\operatorname{SD}(n=3)$.

\section{ABTS radical scavenging assay}

For ABTS [2,2'-azino-bis (3-ethylbenzothiazoline-6sulphonic acid)] assay the standard protocol (Floegel et al., 2011; Shalaby and Shanab, 2013) was followed with slight modifications. Initially, two stock solutions of $7 \mathrm{mM}$ ABTS and $2.4 \mathrm{mM}$ potassium persulfate were prepared. The working stock solution was then prepared by mixing the two solutions in equal volume and was allowed to react for $16 \mathrm{~h}$ at room temperature in the dark. After incubation, the solution was diluted by mixing $1 \mathrm{ml}$ of ABTS-+ with $60 \mathrm{ml}$ methanol to obtain an absorbance of 0.706 \pm 0.01 units at $734 \mathrm{~nm}$. For each assay the ABTS++ solution was freshly prepared. Then, $1 \mathrm{ml}$ of aqueous extract was added to $1 \mathrm{ml}$ of ABTS+ solution and was allowed to react for $7 \mathrm{~min}$ at room temperature. After the incubation, absorbance of the reaction mix 
was recorded at $734 \mathrm{~nm}$. Ascorbic acid was used as the experimental standard with which the ABTS radical scavenging capacities of the extracts were compared. The percentage inhibition value was calculated as:

ABTS radical scavenging activity $(\%)=[$ (Abs (control) - Abs $($ sample) $\left.) / \mathrm{Abs}_{(\text {control })}\right] \times 100$

where Abs (control) is the absorbance of the ABTS radical in methanol; $\mathrm{Abs}_{\text {(sample) }}$ is the absorbance of the ABTS in presence of the aqueous extract or standard. The antioxidant value was expressed as $\mathrm{IC}_{50}$, which is defined as the concentration in $\mu \mathrm{g}$ of the dry extract per $\mathrm{ml}$ that inhibits the formation of ABTS radical by $50 \%$. Each value was determined from the slope of the linear regression equation $(\mathrm{y}=\mathrm{mx}+\mathrm{c})$, obtained by plotting the ascorbic acid standard curve. All results were calculated as mean \pm SD $(n=3)$.

\section{Ferric reducing antioxidant power (FRAP) assay}

The ferric reducing power method (Oyaizu, 1986; Chen et al., 2015) was followed for deducing the reducing power of the aqueous extracts. $200 \mu \mathrm{l}$ of extract was added to $500 \mu \mathrm{l}$ of phosphate buffer $(0.2 \mathrm{M}, \mathrm{pH} 6.6)$ and $500 \mu \mathrm{l}$ of $1 \%$ potassium ferricyanide. The reaction mix was then incubated at $50{ }^{\circ} \mathrm{C}$ for 20 min, after which $10 \%$ trichloroacetic acid was added and was subjected to centrifugation at $3000 \mathrm{rpm}$ for $10 \mathrm{~min}$. $700 \mu \mathrm{l}$ of the supernatant was then taken into a fresh tube and to it $700 \mu \mathrm{l}$ of distilled water and $140 \mu \mathrm{l}$ of freshly prepared $1 \%$ ferric chloride solution were added. The absorbance was then recorded at $700 \mathrm{~nm}$. Ascorbic acid was used as the reference standard.

\section{Cytotoxicity and apoptosis studies on Hep G2 cancer cell line}

For the MTT assay (Nguyen et al., 2015), the Hep G2 (human liver hepatocellular carcinoma) cells were harvested during the logarithmic growth phase and seeded in 96-well plates when the cell density in the culture flask had attained 70-80\% confluency. In each well, a cell density of $3 \times 10^{3}$ cells in a volume of $100 \mu \mathrm{l}$ was maintained and the plate was incubated for $24 \mathrm{~h}$ in a $\mathrm{CO}_{2}$ incubator. The crude extracts were prepared as a stock of 1 $\mathrm{mg} / \mathrm{ml}$ in the Dulbecco's Modified Eagle's Medium (DMEM). The cells were then treated with increasing concentrations of the crude extracts $(10,25,50,100 \mu \mathrm{g} / \mathrm{ml})$ for $48 \mathrm{~h}$ in a $\mathrm{CO}_{2}$ incubator. $10 \mu \mathrm{l}$ of MTT [3- (4,5-dimethylthiazol-2-yl)-2,5-diphenyl tetrazolium bromide] solution $(5 \mathrm{mg} / \mathrm{ml}$ in PBS, $\mathrm{pH} 7.2)$ was then added to each well and the plate was further incubated for $4 \mathrm{~h}$ in an incubator. After incubation, the medium was carefully decanted to air-dry the formazan crystals in dark. Later, $100 \mu \mathrm{l}$ of DMSO was added to the wells followed by gentle shaking to solubilize the formazan dye for $15 \mathrm{~min}$ at room temperature. Absorbance was then measured using a Synergy H4 microplate reader at $570 \mathrm{~nm}$ and the percent cell viability was calculated.

In order to determine the level of apoptosis in Hep G2 cells, DAPI (4',6-diamidino-2-phenylindole) staining method was performed (Lian et al., 1998). The Hep G2 cells were treated with respective crude extracts at its $\mathrm{IC}_{50}$ concentration and incubated for 24 hours. The cells were then harvested and pelleted by centrifugation at $1100 \mathrm{rpm}$ for $10 \mathrm{~min}$. The medium was aspirated and cells were re-suspended in $1 \mathrm{ml}$ PBS. Again the cells were pelleted and $1 \mathrm{ml}$ of permeabilization buffer (PBS/0.01 M glycine/0.1\% Triton X-100) was added followed by incubation for $10 \mathrm{~min}$ with gentle rocking. The cells were re-washed with $1 \mathrm{ml}$ PBS and fixed with $1 \mathrm{ml}$ of $2 \%$ paraformaldehyde in PBS buffer containing $10 \mu \mathrm{g}$ of DAPI $[2 \mu \mathrm{l}$ from stock: $5 \mathrm{mg} / \mathrm{ml}$ DAPI solution in N,N-Dimethyl formamide (DMF)] for $10 \mathrm{~min}$ in the dark. The stained cells were then washed in $1 \mathrm{ml}$ PBS for $5 \mathrm{~min}$. Finally an aliquot was put onto a clean slide, mount with a coverslip and apoptotic cells were observed using a fluorescent microscope at an excitation wavelength of 350nm. The Image J (Version 2.1) software was used for calculating the pixel value statistics of the stained cells that helps quantify the score of DNA damage in the form of a density histogram which represents normalized values of the treated cells against control.

\section{Determination of the anticoagulant activity}

The crude extracts for the assays were prepared by dissolving the dried extract in normal saline $(0.9 \%$ sodium chloride) at different concentrations. Blood samples were collected from 4 healthy volunteers using disposable polypropylene syringe and $3.8 \%$ tri-sodium citrate ( 9 parts of blood to 1 part of trisodium citrate solution) as the anticoagulant. The blood was immediately centrifuged at $4000 \mathrm{x} \mathrm{g}$ for $15 \mathrm{~min}$. The freshly prepared plasma was separated, pooled and was stored at $4{ }^{\circ} \mathrm{C}$ for use in the assay. The steps followed in this assay had been adapted from (Kathiresan et al., 2006), with slight modifications.

In this study, the action of the crude extracts in the intrinsic and common blood coagulation pathway is evaluated by the APTT assay and that of the extrinsic pathway is determined by the PT assay. In the APTT assay, $0.1 \mathrm{ml}$ of the blood plasma was added to $0.1 \mathrm{ml}$ of Liquicelin-E (a phospholipid preparation derived from the rabbit brain with ellagic acid as an activator) and shaken briefly to mix them. The reaction tube was incubated at 37 ${ }^{\circ} \mathrm{C}$ for $20 \mathrm{~min}$. After incubation, $0.1 \mathrm{ml}$ of pre-warmed calcium chloride solution was forcibly added into the reaction tube. Finally, $0.1 \mathrm{ml}$ of each of the already prepared saline plant extracts of different concentrations $(100,500,1000 \mu \mathrm{g} / \mathrm{ml})$ were added to separate reaction tubes and kept at $37{ }^{\circ} \mathrm{C}$. The tubes were shaken gently and tilted back and forth to allow the mixing of the reaction and the time taken to coagulate was recorded in seconds using a stopwatch. As soon as the clot formation begins the stopwatch is stopped. The assay was carried out in triplicates for each sample and the average value was noted and the activity was expressed as clotting time ratio in relation to the control taken, which is heparin.

In the PT assay, $0.1 \mathrm{ml}$ of the blood plasma was taken in a tube and was placed on a water bath at $37^{\circ} \mathrm{C}$ for $3-5 \mathrm{~min}$. To this $0.2 \mathrm{ml}$ of pre-warmed $\left(37^{\circ} \mathrm{C}\right)$ Liquiplastin reagent (liquid calcified Thromboplastin reagent, derived from rabbit brain) was added. And then $0.1 \mathrm{ml}$ of the already prepared saline plant extracts of different concentrations $(100,500,1000 \mu \mathrm{g} / \mathrm{ml})$ were added to 
separate tubes and kept at $37{ }^{\circ} \mathrm{C}$. The time required for the formation of clot was recorded similar to that in the APTT assay.

\section{Statistical analysis}

The results of all series of experiments were performed in triplicates and were expressed as mean \pm SD (standard deviation). Quantitative and graphical data were analyzed using GraphPad Prism 5 software and Microsoft Excel 2011 Package. The data in apoptosis study was analyzed using ImageJ (Version 2.1) package, a public domain, JAVA based image processing software developed at the National Institutes of Health (NIH).

\section{RESULTS AND DISCUSSION}

\section{Phytochemical screening of aqueous extracts}

The aqueous extracts of roots of Acanthus ilicifolius and leaves of Lumnitzera racemosa showed the presence of several classes of bioactive compounds (Table 1). These are the chemical compounds produced in plant tissues as a result of their defense mechanism and are known to have several health benefits (Gavamukulya et al., 2014). The presence of the above class of compounds in the crude extracts validates the presence of molecules that are extensively used in the field of medicine (traditional and pharmaceutical industry) and also weighs on the importance of traditional knowledge for use of plants in drug discovery process.

Table 1: Results of preliminary phytochemical screening of the aqueous plant extracts.

\begin{tabular}{|c|c|c|c|}
\hline Phytochemicals & Name of Tests & 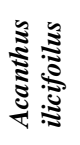 & 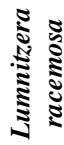 \\
\hline \multirow[t]{2}{*}{ Phenols } & Ferric chloride test & + & + \\
\hline & Gelatin test & + & + \\
\hline \multirow[t]{2}{*}{ Flavonoids } & Ferric chloride test & + & + \\
\hline & Alkaline reagent test & + & + \\
\hline Alkaloids & Wagner's test & + & + \\
\hline Terpenoids & Salkowski’s test & + & + \\
\hline Sterols & Libermann-Burchard test & + & + \\
\hline Tannins & Braymer's test & + & + \\
\hline Proteins and Amino acids & Biuret test and Ninhydrin test & - & - \\
\hline Carbohydrates & Molisch's test & + & + \\
\hline Cardiac glycosides & Keller-Kiliani test & + & + \\
\hline Saponins & Foam test & + & + \\
\hline Quinones & - & + & + \\
\hline
\end{tabular}

Total phenolic content (TPC) \& Total flavonoid content (TFC)

The total phenolic content and total flavonoid content of the extracts were expressed as $\mu \mathrm{g} / \mathrm{ml}$ of gallic acid equilavent (GAE) and quercetin equivalent (QE), respectively (Table 2). The TPC in the extracts were determined from the gallic acid calibration curve with a regression equation of $y=0.0046 x+0.0891$ and $\mathrm{R}^{2}=0.995$ (Figure 1). And the TFC in the extracts were determined from the quercetin calibration curve with a regression equation of $\mathrm{y}=0.0096 \mathrm{x}+0.0521$ and $\mathrm{R}^{2}=0.993$ (Figure 2). The values clearly indicate and confirm the presence of phenolic compounds in the leaf extract of Lumnitzera racemosa as well as in the root extracts of Acanthus ilicifolius and literature data abounds in reports that supports the fact that higher phenolic content directly contributes to the overall antioxidant activity of the extract (Luximon-Ramma et al., 2002). The antioxidant activity of the phenolic compounds is due to their redox properties, which can play an important role in absorbing and neutralizing free radicals, quenching singlet and triplet oxygen, or decomposing peroxides (Saha et al., 2009).

Table 2: TPC and TFC of the aqueous plant extracts $(n=3)$. Values are mean \pm $\mathrm{SD}$

\begin{tabular}{lll}
\hline \multicolumn{1}{c}{ Crude Extract } & \multicolumn{1}{c}{$\begin{array}{c}\text { Acanthus } \\
\text { ilicifolius }\end{array}$} & \multicolumn{1}{c}{$\begin{array}{c}\text { Lumnitzera } \\
\text { racemosa }\end{array}$} \\
\hline Total phenol content $(\mu \mathrm{g} / \mathrm{ml}$ of GAE $)$ & $200.98 \pm 0.004$ & $476.37 \pm 0.007$ \\
Total flavonoid content $(\mu \mathrm{g} / \mathrm{ml}$ of $\mathrm{QE})$ & $17.28 \pm 0.005$ & $24.96 \pm 0.004$ \\
\hline
\end{tabular}

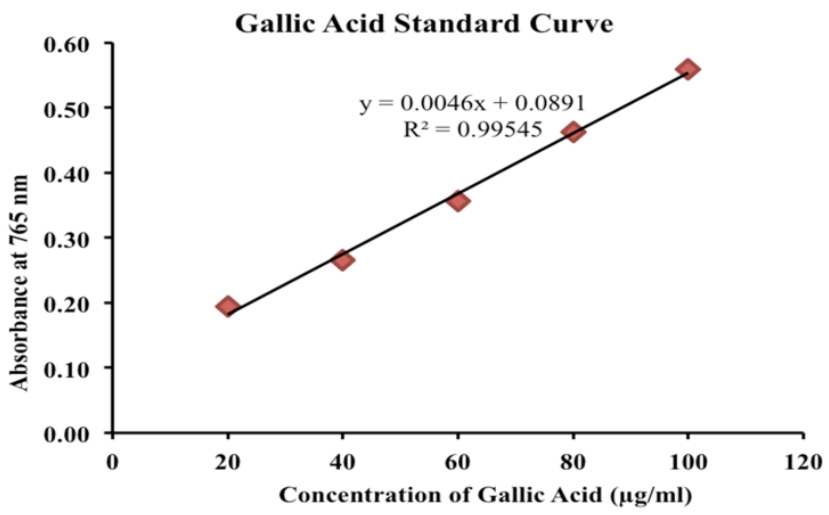

Fig. 1: Gallic acid standard calibration curve.

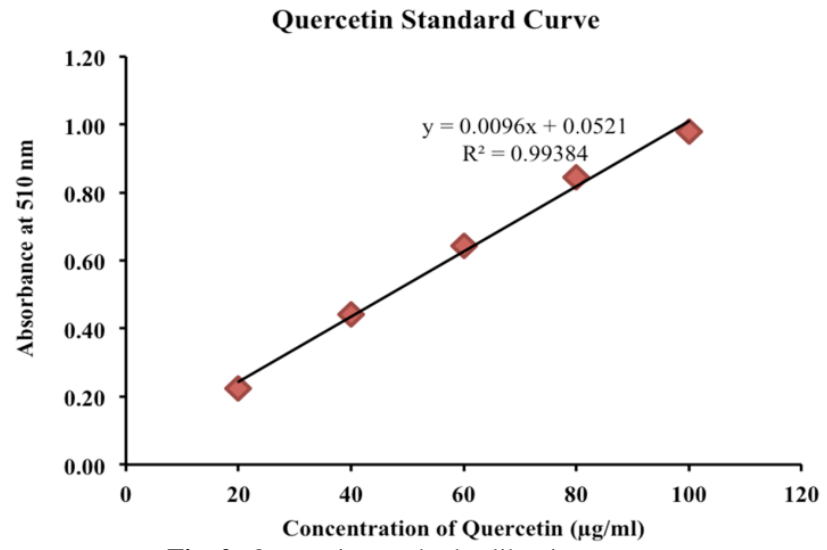

Fig. 2: Quercetin standard calibration curve.

In vitro antioxidant assays

DPPH radical scavenging activity and ABTS radical scavenging activity

Figure 3 clearly shows a decrease in the concentration of DPPH due to the scavenging capability of the plant aqueous extracts. The percentage scavenging effect increases with the simultaneous increase in the concentration of extracts. This concludes that the leaf extracts of Lumnitzera racemosa is an efficient DPPH-free radical scavenger, exhibiting a lower $\mathrm{IC}_{50}$ 
value of $38.89 \mu \mathrm{g} / \mathrm{ml}$ which is in fair proximity to the $\mathrm{IC}_{50}$ value of the experimental standard, ascorbic acid $(21.71 \mu \mathrm{g} / \mathrm{ml})$, thus proving to have good antioxidant power.

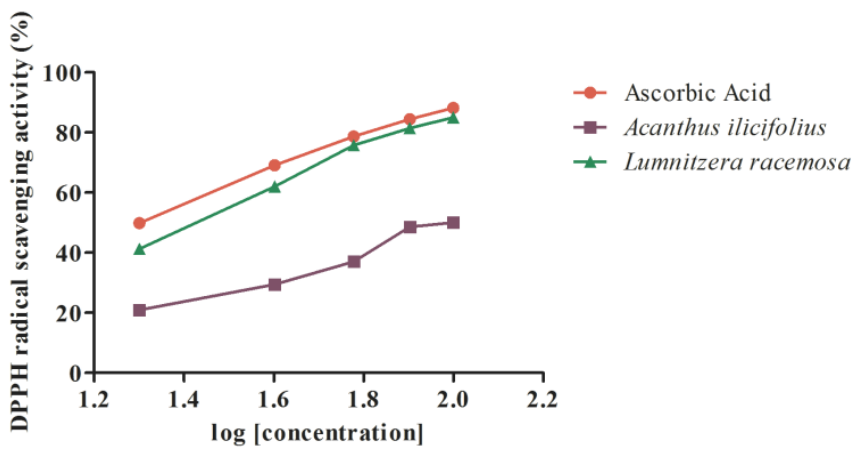

Fig. 3: Antioxidant activity of the crude extracts on DPPH.

Similarly in the ABTS radical scavenging activity assay too, the scavenging effect increases with the increase in the concentration of the plant extracts (Figure 4) and the $\mathrm{IC}_{50}$ values of the leaf extracts of Lumnitzera racemosa and the root extracts of Acanthus ilicifolius were calculated as $44.38 \mu \mathrm{g} / \mathrm{ml}$ and 60.89 $\mu \mathrm{g} / \mathrm{ml}$ respectively. The $\mathrm{IC}_{50}$ value of the experimental standard ascorbic acid was only $19.93 \mu \mathrm{g} / \mathrm{ml}$.

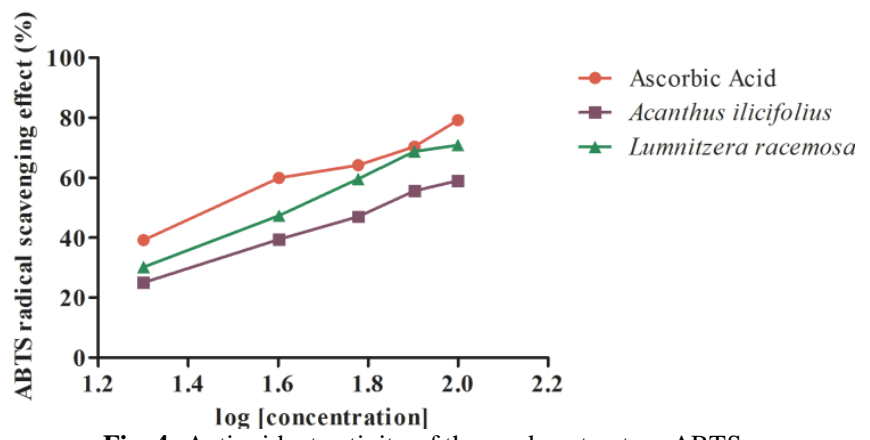

Fig. 4: Antioxidant activity of the crude extract on ABTS.

Table 3: $\mathrm{IC}_{50}$ values of Ascorbic Acid, root extracts of Acanthus ilicifolius and leaf extracts of Lumnitzera racemosa with DPPH and ABTS antioxidant assays $(\mu \mathrm{g} / \mathrm{ml})$.

\begin{tabular}{cccc}
\hline Parameters & $\begin{array}{c}\text { Ascorb } \\
\text { ic Acid } \\
\text { IC }_{\mathbf{5 0}}\end{array}$ & $\begin{array}{c}\text { Acanthus } \\
\text { ilicifolius } \\
\text { root } \\
\text { extract } \\
\text { IC }_{\mathbf{5 0}}\end{array}$ & $\begin{array}{c}\text { Lumnitzera } \\
\text { racemosa } \\
\text { leaf extract } \\
\text { IC }_{\mathbf{5 0}}\end{array}$ \\
\hline DPPH radical scavenging assay & 21.71 & 59.85 & 38.89 \\
ABTS radical scavenging assay & 19.93 & 60.89 & 44.38 \\
\hline
\end{tabular}

The present antioxidant study thus reflects that the plant aqueous extracts, particularly the leaf extract of Lumnitzera racemosa was a potent antioxidant. It showed $85 \% \mathrm{DPPH}$-free radical scavenging activity at $100 \mu \mathrm{g} / \mathrm{ml}$. Also the $\mathrm{IC}_{50}$ values of DPPH assay was lower than the ABTS assay, which might be due to the reason that the aqueous extracts had compounds that are better capable of scavenging the DPPH radicals than the ABTS radicals. According to Mukherjee et al., 2011, various factors like (i) stereo-selectivity of the radicals, (ii) solubility of the extract in different testing systems, (iii) polarity of the solvent, (iv) functional groups present in the bioactive compounds, have been reported to affect the capacity of extracts to react and quench different radicals. In sum, the results of the current antioxidant study comprehends and establishes the possibility of the use of these plant extracts for treatment of free radical induced pathological damages (Aiyegoro and Okoh, 2010).

\section{Ferric reducing antioxidant power (FRAP) assay}

In the FRAP assay, Figure 5 clearly indicates a steady increase in absorbance with the increase in the concentration of plant aqueous extracts which signifies that the ferric reducing ability of the extract increases with increasing concentration. And this reducing capacity is the indication of the extracts having potential antioxidant activity (Babu et al., 2001; Ravikumar and Gnanadesigan, 2011; Firdaus et al., 2013). However, in comparison to the experimental standard ascorbic acid, the plant extracts exhibited moderately lower ferric reducing capability.

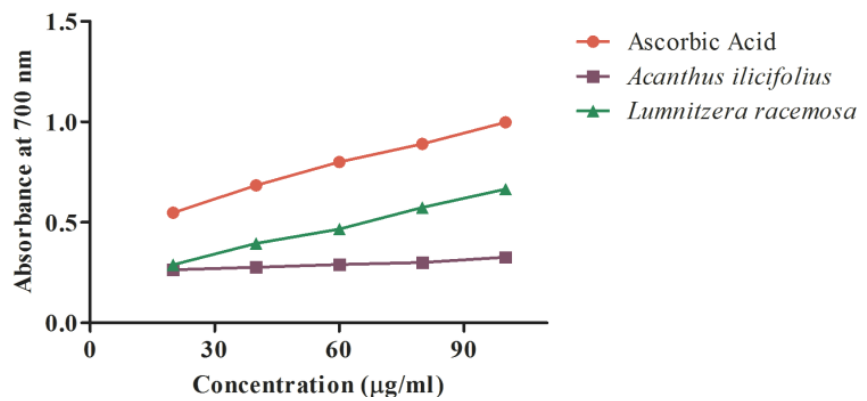

Fig. 5: Reducing power of the crude extracts as compared to ascorbic acid.

\section{Cytotoxicity and apoptosis studies on Hep G2 cancer cell line}

The present study in addition to previously reported studies (Bandaranayake, 2002; Huo et al., 2005; Raut and Khan, 2012; Singh and Aeri, 2013; Huang et al., 2014; Nguyen et al., 2015) suggest that mangroves are a rich source of secondary metabolites probably because they grow and survive under very hostile environmental conditions (high salinity, low nutrition, low oxygen conditions of waterlogged mud and high solar radiation during low tide) (Kathiresan and Bingham, 2001). These naturally occurring bioactive constituents (eg- phenolic compounds) are majorly known to play an important role in the mechanism of anticancer (Babu et al., 2002; Bunyapraphatsara et al., 2003; Van Kiem et al., 2008; Ravikumar and Gnanadesigan, 2011; Firdaus et al., 2013). This is a maiden report of the mangrove plant samples from Pichavaram mangrove forest, Tamil Nadu, India that states the cytotoxicity of the aqueous root extract of Acanthus ilicifolius and leaf extract of Lumnitzera racemosa. In this study the cytotoxic effect of the crude plant extracts were tested against Hep $\mathrm{G} 2$ cancer cell line using MTT assay. The $\mathrm{IC}_{50}$ values for root extract of Acanthus ilicifolius and leaf extract of Lumnitzera racemosa were reported as $39.76 \mu \mathrm{g} / \mathrm{ml}$ and $26.05 \mu \mathrm{g} / \mathrm{ml}$ respectively. Also, the percent cell viability (Figure 6) of the leaf extract of Lumnitzera racemosa exhibited more potent cytotoxicity on Hep G2 cell lines at different concentrations. The higher 
cytotoxicity of the crude extracts may be due to their higher antioxidant potentials or due to the synergistic effect of the multiple bioactive components present in the extract. The antioxidants are capable of scavenging the free radicals that are known to damage healthy cells and is a prime reason for the occurrence of cancer and other free radical induced conditions.

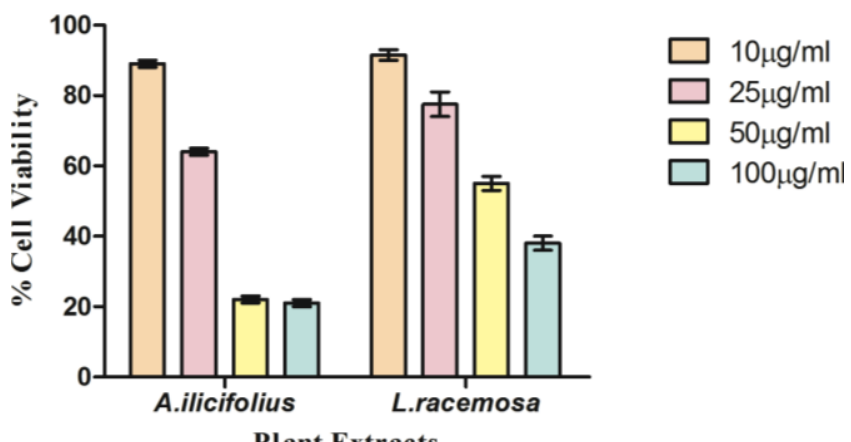

Fig. 6: Effect of the aqueous plant extracts at different concentrations on Hep G2 cancer cells.

Resistance of programmed cell death or apoptosis is an integrated part of the cancer cell development and re-inducing the apoptosis mechanism would be a good indicator of anticancer agent. The apoptosis study was conducted using DAPI staining protocol to examine the apoptosis inducing capability of the crude extracts by determining the score of DNA damage using the ImageJ software. The output is based on pixel value comparison of the treated cells against the control cells. The score for DNA damage (A.ilicifolius $=2.193$ a.u. and L.racemosa $=2.683$ a.u.) in Figure 7, clearly supports our claim of the crude extracts being suitable anticancer agent owing to their apoptosis inducing ability by causing DNA damage. This is at par with a study which proved that any extract had anticancer and cytotoxic activity if it had an $\mathrm{IC}_{50}$ value less than $1000 \mu \mathrm{g} / \mathrm{mL}$ after $24 \mathrm{~h}$ contact time, and that the smaller the $\mathrm{IC}_{50}$ value of a test compound, the more toxic the compound was (Gavamukulya et al., 2014). However, further detailed studies should be conducted to decode the anti cancer mechanism by the crude extracts.

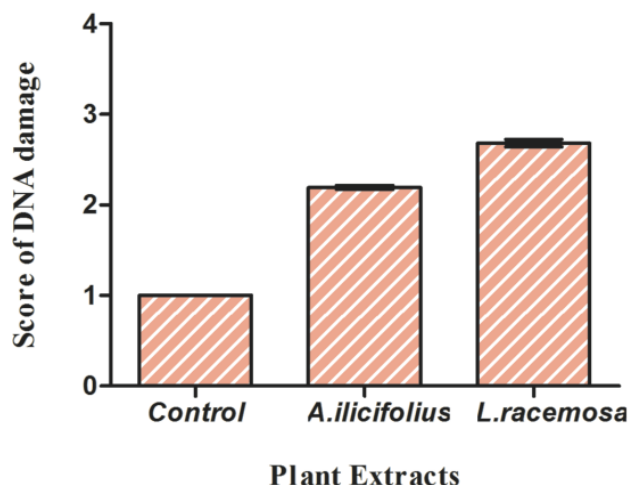

Fig. 7: Effect of aqueous plant extracts on inducing cell apoptosis.

\section{Determination of anticoagulant activity}

Heparin is majorly used for limiting blood coagulation in the field of medicine. But owing to some of its side effects like hemorrhage there has been an urge to look for an alternate to it and hence researchers have been trying to find anticoagulant from natural sources (Edemeka and Ogwu, 2000; Félix-Silva et al., 2014; Khouya et al., 2015). The anticoagulant study involving the APTT and PT assays using normal citrated plasma is an attempt to check the anticoagulation effect of these mangrove plant extracts. Studies however suggest that the anticoagulant property of mangrove plant extract varies over a great range depending on the species and also on the part of the plant (Kathiresan et al., 2006). This assay was performed just to check and report if the plants exhibited anticoagulant property. This is the maiden report for the plants used in this study.

The results show that both the assays vary slightly in the anticoagulant activity and the prolongation of the APTT is slightly higher than the PT in case of both the plant extracts. Table 4 indicates that aqueous extracts of A.ilicifolius and L.racemosa had only slightly prolonged the coagulation times compared with the control sample treated with PBS, suggesting that extracts inhibited the common pathways but isn't too effective compared to Heparin. A previous research however showed that certain other mangrove species like Aviccenia marina, Aegiceras corniculatum exhibited a higher anticoagulant property (Kathiresan et al., 2006), which further proves that the property is totally independent of the plant genera and varies greatly with regional location.

Table 4: Clotting time ratio in mangrove extracts assayed by using APTT and PT methods. The clotting ratio is the time taken for blood clotting in the mangrove extracts treated to the control. The clotting time for control was $80 \mathrm{~s}$ and $32 \mathrm{~s}$ for APTT and PT methods respectively.

\begin{tabular}{lcccccc}
\hline & \multicolumn{4}{c}{ Clotting Time Ratio } \\
\cline { 2 - 7 } \multicolumn{1}{c}{ Mangrove Species } & \multicolumn{3}{c}{ APTT Assay } & \multicolumn{3}{c}{ PT Assay $(\boldsymbol{\mu g} / \mathbf{m l})$} \\
\cline { 2 - 7 } & $\mathbf{1 0 0}$ & $\mathbf{5 0 0}$ & $\mathbf{1 0 0 0}$ & $\mathbf{1 0 0}$ & $\mathbf{5 0 0}$ & $\mathbf{1 0 0 0}$ \\
\hline Acanthus ilicifolius & 1.3 & 1.35 & 1.5 & 1 & 1.25 & 1.31 \\
Lumnitzera racemosa & 1.2 & 1.4 & 1.6 & 1.25 & 1.31 & 1.34 \\
$\begin{array}{l}\text { Heparin } \\
\text { (Positive Control) }\end{array}$ & 315 & - & - & 120 & - & - \\
\hline
\end{tabular}

\section{CONCLUSION}

We have investigated the aqueous extracts of the mangroves for their phytochemical constituents, in vitro antioxidant, anti-cancer and anticoagulant activities to scientifically validate their folklore use in treatment of diseases. This is a first hand report that provides sufficient evidence for carrying out further research on the selected plants to decipher the exact mechanism involved in anticancer and anticoagulant activity. Thereby suggesting in vitro, in vivo and secondary metabolite profiling studies to unravel and identify the bioactive compound(s) responsible, and ultimately provide alternative treatment strategies. 


\section{ACKNOWLEDGEMENT}

The School of Bio Science \& Technology (SBST), VIT University, Vellore, India, financially supported this study. The authors would like to thank VIT University for providing with necessary research facilities. The authors are also grateful to Dr K Kathiresan, Dean, Faculty of Marine Sciences, Centre of Advanced Study in Marine Biology (Annamalai University), Parangipettai, Tamil Nadu, India, who facilitated and helped in the collection \& authentication of the mangrove samples.

\section{Financial support and sponsorship: Nil.}

Conflict of Interests: There are no conflicts of interest.

\section{REFERENCES}

Ainsworth EA, Gillespie KM. Estimation of total phenolic content and other oxidation substrates in plant tissues using FolinCiocalteu reagent. Nat Protoc, 2007;2 (4):875-7.

Aiyegoro OA, Okoh AI. Preliminary phytochemical screening and in vitro antioxidant activities of the aqueous extract of Helichrysum longifolium DC. BMC Complement Altern Med, 2010;10:21.

Babu BH, Shylesh BS, Padikkala J. Antioxidant and hepatoprotective effect of Acanthus ilicifolius. Fitoterapia, 2001;72 (3):272-7.

Babu BH, Shylesh BS, Padikkala J. Tumour reducing and anticarcinogenic activity of Acanthus ilicifolius in mice. J Ethnopharmacol, 2002;79 (1):27-33.

Bandaranayake WM. Traditional and medicinal uses of mangroves. Mangroves Salt Marshes, 1998.

Bandaranayake WM. Bioactivities, bioactive compounds and chemical constituents of mangrove plants. Wetlands Ecology and Management, 2002; 10 (6):421-52.

Banerjee D, Chakrabarti S, Hazra AK, Banerjee S, Ray J, Mukherjee B, et al. Antioxidant activity and total phenolics of some mangroves in Sundarbans. African J Biotechnol, 2008; 7 (6):805-10.

Barku VYA, Opoku-Boahen Y, Owusu-Ansah E, Mensah EF. Antioxidant activity and the estimation of total phenolic and flavonoid contents of the root extract of Amaranthus spinosus. Asian J Plant Sci Res, 2013;3 (1):69-74.

Bunyapraphatsara N, Jutiviboonsuk A, Sornlek P, Therathanathorn W, Aksornkaew S, Fong HHS, et al. Pharmacological studies of plants in the mangrove forest. Thai J Phytopharm, 2003;10 (2).

Chen Y-L, Sung J-M, Lin S-D. Effect of extraction methods on the active compounds and antioxidant properties of ethanolic extracts of Echinacea purpureaflower. Am J Plant Sci, 2015; 6 (6):201-12.

Edemeka DBU, Ogwu AS. Blood coagulation activities of the leaf extracts of Ocimum gratissimum plant in man. J Herbs Spices Med Plants, 2000; 7 (4):9-14.

Félix-Silva J, Souza T, Camara RBG, Cabral B, Silva-Júnior AA, Rebecchi IMM, et al. In vitro anticoagulant and antioxidant activities of Jatropha gossypiifolia L. (Euphorbiaceae) leaves aiming therapeutical applications. BMC Complement Altern Med, 2014; 14:405.

Firdaus M, Prihanto AA, Nurdiani R. Antioxidant and cytotoxic activity of Acanthus ilicifoliusflower. Asian Pac J Trop Biomed, 2013;3 (1):17-21.

Floegel A, Kim D-O, Chung S-J, Koo SI, Chun OK. Comparison of ABTS/DPPH assays to measure antioxidant capacity in popular antioxidant-rich US foods. J Food Compos Anal, 2011;24 (7):1043-8.

Gavamukulya Y, Abou-Elella F, Wamunyokoli F, AEl-Shemy $\mathrm{H}$. Phytochemical screening, anti-oxidant activity and in vitro anticancer potential of ethanolic and water leaves extracts of Annona muricata (Graviola). Asian Pac J Trop Med, 2014;7S1:S355-63.
Huang M-Y, Zhong L-J, Wang F, Liu Q-Y, Zhang Y-H. Chemical constituents from the roots of Acanthus ilicifolius var. xiamenensis. Biochem Syst Ecol, 2014; 55:145-7.

Huo C, Zhao Y, Liang H, Lin W. Studies on chemical constituents in herbs of Acanthus ilicifolius. Zhongguo Zhong Yao Za Zhi, 2005;30:763-5.

Kathiresan K, Bingham BL. Biology of mangroves and mangrove Ecosystems. Adv Mar Biol, 2001; 40:81-251.

Kathiresan K, Ravindran VS, Muruganantham A. Mangrove extracts prevent the blood coagulate! Indian J Biotechnol, 2006;5:252-4.

Khouya T, Ramchoun M, Hmidani A, Amrani S, Harnafi H, Benlyas M, et al. Anti-inflammatory, anticoagulant and antioxidant effects of aqueous extracts from Moroccan thyme varieties. Asian Pac J Trop Biomed, 2015;5 (8):636-44.

Van Kiem P, Quang TH, Huong TT, Nhung LTH, Cuong NX, Van Minh C, et al. Chemical constituents of Acanthus ilicifolius L. and effect on osteoblastic MC3T3E1 cells. Arch Pharm Res, 2008;31 (7):8239.

Lian F, Bhuiyan M, Li Y, Wall N, Kraut M, Sarkar FH. Genistein-induced G2-M arrest, p21WAF1 upregulation, and apoptosis in a non-small-cell lung cancer cell line, 1998; 31 (3):184-91.

Luximon-Ramma A, Bahorun T, Soobrattee MA, Aruoma OI Antioxidant activities of phenolic, proanthocyanidin, and flavonoid components in extracts of Cassia fistula. J Agric Food Chem, 2002;50 (18):5042-7.

Mukherjee S, Pawar N, Kulkarni O, Nagarkar B, Thopte S, Bhujbal A, et al. Evaluation of free-radical quenching properties of standard Ayurvedic formulation Vayasthapana Rasayana. BMC Complement Altern Med, 2011; 11 (1):38.

Nguyen PT, Bui TTL, Chau ND, Bui HT, Kim EJ, Kang HK, et al. In vitro evaluation of the antioxidant and cytotoxic activities of constituents of the mangrove Lumnitzera racemosa Willd. Arch Pharm Res, 2015;38 (4):446-55.

Oyaizu M. Studies on products of browning reaction. Antioxidative activities of products of browning reaction prepared from glucosamine. Japanese J Nutr Diet, 1986;44 (6):307-15.

Pattanaik C, Reddy CS, Dhal NK, Das R. Utilisation of mangrove forests in Bhitarkanika wildlife sanctuary, Orissa. Indian J Tradit Knowl, 2008;7 (4):598-603.

Raut S, Khan S. Phytochemical fingerprinting of Acanthus ilicifolius Linn. Adv Plant Sci, 2012;25 (2):749-53.

Ravikumar S, Gnanadesigan M. Hepatoprotective and antioxidant activity of a mangrove plant Lumnitzera racemosa. Asian Pac J Trop Biomed, 2011;1 (5):348-52.

Shalaby EA, Shanab SMM. Comparison of DPPH and ABTS assays for determining antioxidant potential of water and methanol extracts of Spirulina platensis. Indian J Geo-Marine Sci, 2013;42 (5):55664.

Singh D, Aeri V. Phytochemical and pharmacological potential of Acanthus ilicifolius. J Pharm Bioallied Sci, 2013;5 (1):17-20.

Solomon Charles Ugochukwu, Arukwe Uche I, OnuohaI. Preliminary phytochemical screening of different solvent extracts of stem bark and roots of Dennetia tripetala. Asian J Plant Sci Res, 2013;3 (3):103 .

Zheleva-Dimitrova D, Nedialkov P, Kitanov G. Radical scavenging and antioxidant activities of methanolic extracts from Hypericum species growing in Bulgaria. Pharmacogn Mag, 2010; 6 (22):74.

How to cite this article:

Paul T, Ramasubbu S. The antioxidant, anticancer and anticoagulant activities of Acanthus ilicifolius L. roots and Lumnitzera racemosa Willd. leaves, from southeast coast of India. J App Pharm Sci, 2017; 7 (03): 081-087. 